\title{
T-Cell Receptor Gamma Chain Alternative Reading Frame Protein Isoform 1
}

National Cancer Institute

\section{Source}

National Cancer Institute. T-Cell Receptor Gamma Chain Alternative Reading Frame

Protein Isoform 1. NCI Thesaurus. Code C88930.

T-cell receptor gamma chain alternative reading frame protein isoform 1 (58 aa, $~ 7 \mathrm{kDa}$ )

is encoded by the human TARP gene. This protein may be involved in prostate function. 